\title{
Preface: The Place of Narrative
}

\author{
Carol Jacobs
}
The landscape "as such" is never given, only one or another of the ways to map it.
-J. Hillis Miller, Topographies, 6

An act of reading is the space produced by the practice of a particular place.

-Michel de Certeau, cited in W. J. T. Mitchell's essay in this volume

We solicited essays from some of the most challenging thinkers in literary theory today, under the proposed title Acts of Narrative. Narrative, if we are to believe what follows, is everywhere. It greets us at every turn: not only in fiction, poetry, and conventional history, but also in literary history, psychoanalysis, spatial designs, economics, and the conversational exchanges of everyday life. It greets us at every precarious turn, and this is perhaps what ties these essays together, fraught with social and political implications, and haunted by lies, deceit, and the inevitable abyss of death.

If each of these essays reads narrative, it is certainly not because they read the same thing or produce the same spaces. Still, gathering them within the same volume suggests that they might, nevertheless, share the same turf, or, to once again read de Certeau's phrase out of context, that they might practice the particular place we have agreed to call narrative. To speak of narrative, and also to speak it, is not, perhaps, unlike the practice of certain landscape artists. We might look to J. M. W. Turner in this regard, an exemplary figure in the English school of landscape painting. $\mathrm{He}$ was not adverse, and in this he was not alone, to practicing a particular place and to practicing it differently. The Passage of Mount St. Gothard, to take a well-known if hardly random image, tells one story if, in Turner's famous watercolor ("The Passage of Mount St Gothard, taken from the center of the Teufels Bruch [Devil's Bridge]"), one regards the two pack mules making their way laboriously along the mountainside behind a protective wall and another if in the almost identical oil ("The Pass of St Gothard") 
the eye falls on an ascetic religious figure who worships the image of his martyred god at the edge of the precipice. It tells one story if taken from the center of the "Teufels Bruch" and quite another if it depicts the bridge itself (as in the oil "The Devil's Bridge, St Gothard"). And there is another story of bridges and breaks that the Passage will tell, given time.

With respect to the essays at hand it seemed to go, almost without saying, not only that narrative is performance, but that while these essays might be about narrative, they themselves would also be narrative acts. What then is the role of the editors asked to account for the multiplicity of acts to follow? What kind of a story is one called upon to tell? The preface to a book, as its etymology tells us, is a saying beforehand, a saying beforehand that conventionally paraphrases the content of what is to come. But how could one claim to preface performances? Moreover, an edited volume is, necessarily, a confession of sorts (and its cover-up), that singularity of intention can ever pretend to animate the work. And yet what follows is not without its coherence, which is not to say univocity. We might, with Alan Liu, think of it as networking, or perhaps as a patchwork quilt.

J. Hillis Miller's essay, "Lying Against Death: Out of the Loop," opens with an epigraph from Jean-Luc Nancy, "death does not consummate existence, one would, rather, have to say that it prevents it from turning into essence." One might be tempted to put this another way to describe the criticism of this generous and provocative writer: Miller's writing does not consummate the literary object that it directly or indirectly presents but rather prevents that object, and shows why it must necessarily prevent it, from turning into essence.

And yet over the years we have become spoiled by Miller's absolutely lucid and seemingly straightforward voice that draws us into its orbit, lures us into the complacency of easy understanding, and assures us that we have learned something very definitive from this great business of literary criticism. Still, something always has to be obscured, forgotten, covered over in order for Miller's reader to go on reading. Perhaps nowhere is this clearer than when he speaks of lying, as he not infrequently does.

In "Lying Against Death" Miller writes about Henry James' novel The Wings of the Dove. This aboutness, after all, is the given of literary criticism. And yet if his first paragraph concerns anything, it is about the impossibility of a fiction about something. These opening lines are nevertheless exemplary. For, in a pattern repeated several times in the essay, each succeeding sentence rejects, replaces, and rewrites what came before, giv- 
ing us the sense of an avalanche in the midst of which we are sliding headily fast, but not fast enough to avoid the inevitable. "The Wings of the Dove," we are told, "is in 'essence' a novel about death. James in the preface says so, and there is no reason to doubt his word." And yet what we learn all too rapidly is that there is every reason to doubt the word of the critic, even when he himself has written what he is trying to explain. James is no more to be believed than the characters in his novel, whose "social system is based on a set of lies that everyone knows are lies and yet agrees to pretend to believe." Not entirely unlike the world of literary criticism. The Wings of the Dove is less about death, about which, it turns out, it is impossible to write, than lying in relation to death. "Lying Against Death," as its title almost promises, teases out the obscure, not easily definable, but many ways in which speech acts in general and lying in particular are inextricably bound up with death in the course of the novel.

The expression of the heroine's state along with the relation of the writer to it, Miller reminds us, are linked to insoluble mysteries according to James. And over the next several pages, once again, Miller performs a characteristic slide from one yet to be rejected formulation to the next. The novel is not so much about a dying woman as about the heroine's resistance to death. Moreover, that "defiance of death can only be represented" by way of "indirect presentation." Yet this creature, doomed from the very beginning to death and to be victimized by the society that seems to dote on her, is, Miller tells us, "an extreme danger to all those who have anything to do with her." She draws people away from their "'natural orbits," like "the sinking of a big vessel or the failure of a great business."

It is, no doubt, a frivolous comment, one based on mere accidents of the spelling of proper names. Still, as we are reminded in this essay that James based his main character, Milly, on his cousin "Minny," we cannot help but notice the proximity of "Milly" not only to the relative but also to the critic. Does the danger "Miller" attributes to the main character also seem to say something of the critical performance that brings, if not disaster, at least disappointment to those who wish to capitalize on a knowledge gained? For Miller "cannot be used in this way." Let us say that his reader has as much chance of coming away with a fortune as Densher at the close of the novel.

Diane Elam's piece also reads Henry James's The Wings of the Dove. The title to the essay says it all. "Waiting in the Wings" suggests actors prepared to act, prepared to become characters whose set roles they have prac- 
ticed beforehand. Still, no action of that sort, no playing of a role that might be anticipated takes place. And yet, as Elam shows us from the opening line the narrative concerns waiting, waiting of another order.

All the main characters wait and it is through this action, which is not quite perfect stillness, that a "consciousness of temporality" which "structures human existence" emerges. Merton Densher and Kate Croy imagine they can control the future, but what they encounter instead is a consciousness of mortality, that of others, and even their own, a sense of a past that will not hold still and a future that cannot be predicted, much less mastered.

Elam relates this to the fort-da game of the child in Freud's Beyond the Pleasure Principle where a more successful control of loss at least seems to take place. Cathy Caruth will invoke the same lines in Freud to narrate a rather different and unexpected story. It is to this passage that her essay will repeatedly return. To be sure, like that Heraclitian river, it is never the same passage twice. For this and other reasons Caruth's piece is full of surprises. She begins with Freud's astonishment. In the pages that precede his turn to the child's game of "fort-da," he speaks in a famous moment of Beyond the Pleasure Principle, of a puzzling encounter with veterans of World War I. Their dreams, rather than fulfilling wishes, as Freud had come to expect, repeat the traumas of their battle experiences. Thereafter, the dreamers wake up into yet another fright, in a concatenation of the repeated trauma. If trauma, as Freud suggests, is a being taken by surprise, how are we to explain that these unusual dreams doubly reenact that experience?

Moreover, it would seem that reading, and also the narrative accounts of reading, are especially prone to the unexpected. Thus Caruth makes us aware of Freud's remarkable narratival juxtaposition of wartime trauma with the description of a child's game. And, with respect to the latter, she points to Freud's seemingly random oscillations of interpretation, oscillations that repeat the fort-da movement of the child.

But jumps, repetitions, and unpredictable juxtapositions are precisely, one might say, what Caruth's essay is both about and goes about performing. Thus her essay will move from Freud's two scenes in Beyond the Pleasure Principle to an encounter with a child traumatized by the murder of his best friend in Atlanta. And all these partake of yet another leap, that from the death drive to the life drive. Trauma becomes the imperative to awaken, to live, to create. A shift takes place along the way, unexpected in Freud, from an analysis of childhood to a far broader perspective of vast 
cultural scope in which trauma becomes the opportunity for the creative acts of making history. The creative act, then, which seemed located in the veteran's awakening into survival, and in the child's game in the wake of its mother's departure, has its repetition in the gesture of Freud's exposition.

Freud struggles with the events he reads in Beyond the Pleasure Principle, as he repeats their stories at a distance and thereby creates a new language that enacts the drive for life and a new departure into history. In this essay so filled with surreptitious shifts and seemingly compulsive repetitions, Caruth, too, accounts not only for Freud and the interviews of the traumatized Atlanta youth, but struggles with an event more quietly announced in her essay. Side by side with the more obvious objects of her concern, Caruth repeats, in a sense, the death of Freud's daughter, announced in a footnote of his essay. Caruth too enacts the drive for life. It takes place in the wake of her mother's death, quietly memorialized in an epigraph and footnote. Thus she performs for us, once again, in this echo chamber of textual repetitions, the failure of the mind to grasp an event it must inevitably miss.

It is to Freud's narratives and their oscillations that Rachel Bowlby also turns. "The Other Day" explores, to begin with, the role that the residues of our waking hours play in his structurings of the dream and the shifting divisions that Freud marks out between daydreams and "nightdreams." It would be easiest to assume, and Freud often asks us to do so, that they are as different as night and day. Yet if Bowlby sheds light on this question, it is by plunging us into the realm of ambiguities that Freud's texts impose. The two are sometimes alike and sometimes not. For as Bowlby takes us on a wide-flung trajectory through Freud's works we find that the daydream can give significance to the dreams of the night either by contrast or by analogy. Are we to regard the events of the day that make their way into the dream as superficial and transitory, of little or no significance, a transparent cover story that draws attention away from the latent dream thoughts of the night's hallucinatory production? Or are we, rather, to recognize, as Freud not infrequently does, the similarity of the two, a similarity so powerful that the daydream, it too touching on the unconscious, might well serve as a model for our understanding of its counterpart?

The complexity of this relationship becomes evident, if hardly transparent, as Bowlby reads Freud reading a scene of the daydream in the fiction of Alphonse Daudet. But what Freud writes in The Interpretation of 
Dreams he displaces and interprets in The Psychopathology of Everyday Life. And what Freud writes in the Psychopathology Bowlby rewrites, with irony and relevance to the issue of the dream, with irony and relevance as well to the issue of Freud's ambition. For Freud's multiple misrememberings of the fiction of Daudet, which Bowlby traces out with patience, say a great deal about relations of superiority and dependence, activity and passivity, perhaps not unlike the act of interpretation itself.

Bowlby is concerned with the rememberings and misrememberings of Freud, whereas Dan Shen theorizes the kind of narrations that Freud produces as he remembers. Her concern is the first-person retrospective narrative and some of the differences in focalization or point of view between such a mode and third-person narratives. What happens, Shen asks, when the narrator sees the world through the eyes of a character? How are we to account for the dual nature of that character's perceptions, both as elements of the story told and as elements of the discourse?

When the third-person is the center of consciousness, what latitudes or rather constrictions guide the telling? In the case of a first-person narration the narrative possibilities are suspended between the more conventional retelling from the perspective of the current moment's hindsight and a recounting of matters as they took place in the past. When the two perspectives become confused, when the skill of the author is such that the reader is taken in, suddenly experiencing the world much like the character in earlier times, we have a narration that uses the first-person mode to perform the ambiguities of perception or to obliterate the distinction between present and past. Shen tells her story by turning to Joyce, Fitzgerald, James, and Proust. She cites, comments, and then often rewrites their prose to give us a sense how it might have been otherwise if the focalization had been shifted.

If Shen is out to alter the concept of focalization, Nicholas Royle is rather in favor of discarding it altogether. "The 'Telepathy Effect': Notes toward a Reconsideration of Narrative Fiction" alerts us to a flawed story we have been telling ourselves ever since it has been a question of narrative theory, at least since the end of the eighteenth century. This is an "incoherent" story with a "flawed plot-device," a reassuring tale that has all the comforts and certainty of theological belief in an omniscient deity. Indeed the concept of "omniscient narrator" that Royle wishes to dispel finds its etymological and conceptual origins precisely in a religious terminology that describes the all-knowing Christian God. If we have held on to the con- 
cept, Royle suggests, it is perhaps because we, too, as readers, have thus been able to partake of that delusive sense of knowledge, assuming "the experience of reading" to assert or presuppose "a fixed and totalizing interpretation."

In place of omniscience, Royle suggests "telepathy." It is, in a sense, the shift from dogma to the "uncanny," a term that surreptitiously, as so many of these essays do, returns us to the author who gave that term its most urgent dissemination. For, as Royle tells it, the concept of "omniscient narration" freed the literary critic from any real encounter with psychoanalysis, substituting religious certainty for the uneasy "logic of the unconscious." Historically this takes place just when Freud's thinking about the "impossibility of complete knowledge" should have become an unavoidable obstacle to such thinking. Royle criticizes this flight from the unconscious, but his is no call to the scientific claims of Freud nor to any simple truth psychoanalysis might offer us about the literary text. "Telepathy" operates precisely as a literary force that eludes not only the fixations of religion but also those of psychoanalysis as scientific methodology. It also eludes the promise of those other, related terms, "point of view" and "focalization" which presuppose a reducible simplified "'unitariness' of the figures of 'author,' 'narrator' and 'character' alike." We get some sense of the telepathic literary force as Royle takes us through passages from Dickens, Woolf, and Rushdie, by way of Derrida's "being-two-to-speak."

Being two-to-read is perhaps what Tom Cohen solicits-bringing us, as he does, to read "race" and reread "race" in Faulkner. Moreover, if in very different ways Caruth, Shen, and Royle tell of profound disturbance to any narratival recuperation of the past, Tom Cohen shows that it is only with such disturbance that epistemo-political transformation takes place. The texts in question are Go Down Moses and its preamble in the form of the story "Was," also "Pantaloon in Black."

Cohen's act of reading concentrates on the tale of a runaway slave. In a story seemingly placed in the historical, representational frame of an antebellum plantation, at the site, then, of a conventional literary reading as well, Cohen remarks on the description of a hunt. This hunt for the slave, a performance ritually repeated by the characters of the story, is also a story that oscillates between and dissolves two models of reading. The runaway slave escapes from predetermined meanings and although ritually returned to them, he creates the excess of the "black hole" and of the "unrepresentable." This race enacts a rupture in the catastrophic history of the 
American South. It alters the way we read, say, the term "race," but many other terms as well, terms that have a peculiar resonance in the passages Cohen reads. The slave acts as signifiers run wild in a ritual of mastery and its disruption to be repeated endlessly.

"Was," then, that referentless past tense verb, and the other works Cohen reads, would not be about the South, would not be about the particular time period that precedes the Civil War. It would transvaluate the apparent decline of Faulkner into realism, historicism, representation. What Cohen terms black reading has a transformative power that moves beyond any literalization of race in the comforting form of identity politics or a regionalist program of Americanists. It brings us to a new sense of magical realism and to a literature no longer American, but of the Americas.

Cohen writes of political transformation that takes place as anteriority, repetition, and other historico-narrational gestures lose ground. Ronald Paulson, however, tells of social struggles in which the historical frame of synchronicity seems crucial. "The Rape of the Lock: A Jacobite Aesthetics?" is a highly complex juggling act. It puts into play not only the three authors named in the title, but also a host of other figures all vying for a space in which to rise and fall, not without some unexpected collisions.

Thus, if a reading of Pope's Rape of the Lock is Paulson's immediate concern, there is no possibility of attentive analysis of literature here without taking into account critical political and religious stakes. Shaftesbury, Whig, anti-Tory, anti-Jacobite, is allied with an aesthetics that arises out of British empiricism and which inevitably speaks of matters theological and social. This is an aesthetics that critiques a Christian deity regarded as tyrannical and punitive and replaces it with a classical Platonic form of far less authoritarian nature. Along the way the parallel figure of the monarch is replaced by the many, or, at least, an oligarchy of connoisseurs and critics. The Jacobites on the other hand would have reversed all this, a return to the monarchy, and to a non-aesthetics linked, not to the reception and support by the many but to God and a poetics based on the poet.

Where then, Paulson asks, are we to situate Pope in all this? While distancing himself from Shaftesbury, in Rape of the Lock Pope gives us a narrative of Christian fall and redemption, a religious redemption allied with hopes of political restoration. This is an aesthetics of the fall rather than of the ideal: and the redemption of the living fallen woman is ultimately through poetry. This is a return then to a poetics based on the au- 
thority of the poet and on God, but also on the monarch, so that Pope's aesthetics of the fall and the blemish is also another politics.

Swift offers a counter-aesthetics to Pope's Rape, rewriting passages and parodying especially the thematized inability therein "to tolerate a human flaw - a blemish of the ideal, an acknowledgement of the Fall." For whereas Pope seems to "[aestheticize] the human condition," Swift dismisses the possibility of an art whose aesthetics could bring about redemption.

Within this constellation of positions, despite the more obvious grounds for difference, Paulson goes on to read the correspondences between Pope and what Hogarth is about in The Analysis of Beauty. Whereas the blemish in Pope calls out for redemption through poet and God, the flaw in Hogarth contributes to the beauty of its object. Thus both Pope and Hogarth reject a Shaftesburian aesthetics of ideal harmony for an "aesthetics of the blemish." Pope does so in the expectation of a redemption, whereas Hogarth chooses rather to celebrate the variety of fallen nature.

W. J. T. Mitchell returns us to Hogarth's "The Analysis of Beauty." "The Serpent in the Wilderness" traces the serpentine and spiral line of the eighteenth century less to represent what took place there, less to claim the form's universal application, than as a path to meditating the concept of the spatial design of a period in general, while yet taking into account the "very specific circumstances of a national culture at a defining moment." Passing by way of a narrative description of Hogarth's work, Mitchell rethinks the serpentine in relation to a topography that has crucial social and political implications. It has critical narrational implications as well, within the movement of Mitchell's writing. For the serpentine is a nationalistic mark of British liberty, on the one hand, but also a commentary on the enclosure movement; a celebration of the English countryside, but also a rejection of the specificity of English place that would suggest, a line that figures British colonial expansion as well. The sinuous form of Hogarth's curiosity and beauty becomes the unfixable line of Mitchell's argument.

For Schleifer, as for Cohen, Paulson and Mitchell, it is history that cannot be ignored, though once again, on very different grounds. Ronald Schleifer's "Narrative Discourse and a New Sense of Value" takes up Alfred Marshall's Principles of Economics, first published at the end of the nineteenth century. This is work that moves from classical economics to "neoclassical" or "marginal" economics. That shift has much resonance with conceptual revolutions we tend to think of as more recent. Thus as 
Schleifer reads Marshall, the names not only of Virginia Woolf, but also J. Hillis Miller, Paul Ricoeur, Jean-Joseph Goux, and Jean Baudrillard echo through the essay.

Marshall's economics leaves behind a "systematic presentation of meaning," for the question of the way in which desire motivates us to act. He is concerned, not with simple utility but with "marginal utility," with that which induces us, just barely induces us, to purchase, to choose one thing rather than another. The way we apprehend value is transformed. In an economics that will stress exchange value rather than inherent value, it is desires that tend to define value and they operate in a system of substitutions.

Neoclassical economics does attempt to quantify, to establish a mathematical accounting. But side by side with this insistence on science, this is Schleifer's point, "'alternating' two modes of apprehension," as he thinks the motivations of desire in marginal utility, Marshall is inextricably bound to "particularities of historical detail." That is to say that Marshall's account makes "time a constituent element in the analysis of value." Neoclassical economics takes place through "story-telling and narrative." Understanding as narrative replaces positivism and a "categoreal mode of comprehension." History here is no fixed temporal structure, but rather that which marks the complexity of the new economics as configuration and relation. It "complicates systematic reasoning" in which everything, the miscellaneous, is constantly changing, in which subordination to principles or abstract meaning is no longer possible.

If storytelling is crucial to neoclassical economics in Schleifer's reading, it is no less critical, Alan Liu tells us, to literary history. "Sidney's Technology" is a story about narratology, more specifically about how we create literary histories and what the difference is between the literary histories of the past and "the so-called 'new literary history." Taking up texts from the sixteenth century to the present, but concentrating on readings from Sidney's Apology, by thinking of literary history as a communications system, Liu scrutinizes "from the perspective of contemporary technology" the way in which literary history is produced.

Conventional "literary history is [first of all] the management of presentations of literature." This "management" wards off the threat of a literal understanding, an "unmediated reading" in which the perception of the work might immediately call forth its essence. This repudiation of the immediately understandable is the origin of literary history, and literary history, Liu argues, is therefore what literature itself has always been. 
Liu turns to Greimas' structural semantics to show (or tell) us just how such management of literal presentation might be understood. The same schemas that apply to literature, schemas of "narrative action ... [as] communications transmission," also apply to the way in which different histories tell their tales. What emerges from this is that literary history comes forth as our sense of tradition. Still, a literal presentation of literature remains a threat even in the literary history that tries to contain it. But Liu locates the meta-management of that threat in the academy, in "the communicational situation of the classroom." Historical consciousness is "what we mean by education in the humanities," and history is that which denies the literal; and thus "denies us our present." Liu, no less than the literature he describes others describing, no less than literary history, no less than educators in the classroom, tells us a story with many layers. If literary history thus socializes representations of literature, there is a general "pragmatics of culture" that meta-manages all that went before. This has usually taken place in the name of national culture in which socialization takes place. Still something new appears on the horizon-something carried out by "deconstructive, culturist, and multiculturalist research agendas" alike. The metaphor Liu chooses for it is no longer transmission but "networking."

It is not entirely clear who authored the concluding if not conclusive essay. We solicited a piece from Jacques Derrida. We are publishing the pages that the postal carrier delivered in response. So many narrators, authors, critics, characters, witnesses, perjurers, and perjuries in the mix here: Jacques Derrida, to be sure, but also Henri Thomas, author of the novel Le Parjure, its narrator, Stéphane Chalier, the novel's main character, "who [like Henri Thomas] was no stranger to the real person" Paul de Man, de Man whom both Jacques Derrida and J. Hillis Miller counted as a friend, and J. Hillis Miller whose theories of narrative, lying, and anacoluthon, breach the text from beginning to end.

To simplify: the narrator, impossible narrator, Jacques Derrida, tells us that in the late seventies Paul de Man, uncharacteristically linking knowledge, reading, and life, told him, "If you wish to know a part of my life, read Hölderlin in America." Henri Thomas's Hölderlin in America subsequently became part of the novel The Perjury/Perjuror. A question of lapse in memory, perhaps, the inevitable breach in the thinking of a subject never identical to itself over time, it tells of Stéphane Chalier, who had forgotten himself. "Hospitalized and almost blind" (13), he stands accused of perjury-of entering a second marriage while neither admitting to nor 
terminating his first. The tale has remarkable resonance with anacoluthon as Miller describes it in writing on Proust in Black Holes, with its breaches in syntax, shifts in subject, interruptions of memory: A shift in subject in Thomas's narration such that the narrator as witness, as acolyte, substitutes for and is called upon to assume the guilt of the friend.

But the story that Thomas's narrator tells, it too, is also not identical to itself. Not only because of, as de Man insisted, its relation to a "real" life, but also because its "oblique object," as Derrida cannot help but remind us, is not only that of the young Paul de Man, but also the accompanying story of and storytelling surrounding the "de Man affair" of more recent years. It is this unreadable and impossible story that the narrator does not tell, but asks us, its readers, to interpret.

To be sure there have been many versions of it well before this provocation: perhaps none so blindly telling as the oil on canvas by Mark Tansey entitled "Derrida Queries de Man." It appeared as a postcard some years back (a very different postcard from that which Derrida sends). The setting is Turner's (the painter so critical to Miller's brilliant volume Illustration) "The Passage of Mount St. Gotthard, taken from the centre of the Teufels Bruch": Tansey practices this particular space differently. We find ourselves set into the mock Romantic, faux sublime, of lofty yet peakless mountains that are endlessly inscribed with almost unreadable fragments of text, divided by a treacherous abyss. Human figures which the painting's title names Paul de Man and Jacques Derrida appear at the edge of a precipice, over which the latter is jettisoning the former. Precariously poised, de Man has only a single leg to stand on. What does it mean to be the oblique object of a representation? Is this "oil on canvas" a stranger to the real persons it seems to portray? Who is telling this tale, we might ask. Does Tansey not risk here, not only a bridge to, but also a certain rupture (what the title of Turner's watercolor calls a "Bruch") of memory? What part of their lives could he possibly have known or understood? Was theirs not rather the performance of a pas de deux or even of a pas de deux? How the devil does this work of art destined to become a postcard position itself, politically? What is allegory, what is narrative? Why must all of this be left up in the air? Why must it be what we tend to call a cliffhanger? 
ACTS OF NARRATIVE 
